Jurnal Keuangan dan Perbankan, 23(1):61-77, 2019

http://jurnal.unmer.ac.id/index.php/jkdp

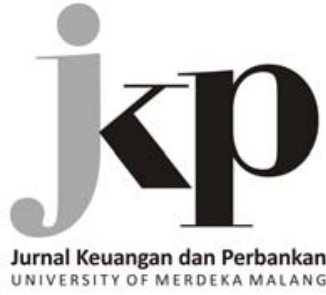

Article history:

Received: 2018-05-22

Revised: 2018-08-07

Accepted: 2018-09-28

Keywords:

Board of Commissioners; Corporate Governance; Firm Performance; Supervisory Functions

JEL Classification: G31, G32, G34

Kata Kunci: Dewan Komisaris; Tata Kelola; Kinerja Perusahaan; Fungsi Pengawasan

$\triangle$ Corresponding Author: Aliffianti Safiria Ayu Ditta: Tel +62 271647481

E-mail: aliffianti14@gmail.com

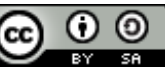

This is an open access article under the CC-BY-SA license

\section{Corporate governance in Indonesia: One decade perspective}

\author{
Aliffianti Safiria Ayu Ditta, Doddy Setiawan \\ Department of Accounting, Faculty of Economics and Business, Universitas Sebelas Maret \\ Jl. Ir. Sutami No.36A Surakarta, 57126, Indonesia
}

\section{Abstract}

This study aim in describing the development of research on corporate governance in Indonesia. The sample of the study consists of 101 articles from 10 Indonesian accredited journals at 2007-2017 periods. This research applies to chart the field method that classifies articles based on topic, disciplines and research methods. Most of the article (40 out of 101 articles) study the consequences of the emergence of corporate governance, such as the performance of the company and most of the article applies the analytical method (96 articles). However, the discussion on Indonesia institutional context, such as two-tier board systems, is still rare. The study mostly focuses on monitoring function of the Board of Commissioners. Most of the study also investigate the effect of corporate governance practice on firm performance. Followed by the effect of corporate governance practice on disclosure. Further, most of the study conducted research on short periods ( 3.5 years). It is expected that this article provides a review of the recent development of corporate governance research in Indonesia and the opportunity to conduct the study.

\section{Abstrak}

Penelitian ini bertujuan menggambarkan pengembangan penelitian mengenai tata kelola perusahaan di Indonesia. Sampel penelitian terdiri dari 101 artikel dari 10 jurnal terakreditasi di Indonesia selama periode 2007-2017. Penelitian ini menerapkan metode charting the field yang mengklasifikasikan artikel berdasarkan topik, disiplin ilmu dan metode penelitian. Sebagian besar artikel (40 dari 101 artikel) membahas mengenai konsekuensi dari munculnya tata kelola perusahaan, seperti kinerja perusahaan dan sebagian besar artikel menerapkan metode analytical (96 artikel). Akan tetapi, pembahasan mengenai konteks spesifik di Indonesia, seperti penerapan two tier board system masib belum banyak dilakukan. Sebagian besar penelitian lebih berfokus pada fungsi pengawasan yang dilakukan oleh Dewan Komisaris. Selain itu, sebagian besar penelitian di bidang corporate governance fokus pada dampak praktik corporate governance terhadap kinerja perusahaan. Selanjutnya penelitian di bidang corporate governance meneliti dampak corporate governance terhadap praktik pengungkapan oleh perusahaan. Lebih jauh lagi, sebagian besar penelitian dilakukan pada periode yang terbilang cukup singkat yakni selama 3,5 tahun. Penelitian ini diharapkan dapat memberikan ulasan terhadap perkembangan penelitian tentang corporate governance di Indonesia dan membuka kesempatan untuk melakukan studi lebih lanjut di bidang corporate governance.

How to Cite : Ditta, A. S. A., \& Setiawan, D. (2019). Corporate governance in Indonesia: Onedecade perspective. Jurnal Kenangan dan Perbankan, 23(1), 61-77. https://doi.org/ 10.26905/jkdp.v23i1.2182 


\section{Jurnal Keuangan dan Perbankan}

Volume 23, Issue 1, January 2019: 61-77

\section{Introduction}

Issues and researches on corporate governance began to develop as the economic crisis hit Asia and globally. In Indonesia, the economic crisis of 1998, making the issue of corporate governance grows bigger and becomes a topic that is often discussed. Poor corporate governance, minimal transparency, are said to be the causes of the economic crisis in 1998 (Wardhani, 2007). The agency theory by Jensen \& Meckling (1976) suggests that conflicts between agents and principal are often caused by information asymmetry, both adverse selection, and moral hazard, making researchers motivated to conduct research linking the emergence of agency conflicts with the importance implementation of good corporate governance. This motivates researchers to see the development of corporate governance research in Indonesia and to evaluate, then to document it in a bibliography.

Research conducted by Sabbaghi (2016) in China states that understanding corporate governance is as important as understanding the role of business ethics related to the integrity and long-term sustainability of capital markets and corporations in China and ensuring that company assets are used efficiently and productively for the benefit of investors and other stakeholders, so that corporate governance is closely related to the role of monitoring for corporate management to work effectively and efficiently achieve the long-term goals and sustainability of the company and to meet the interests of shareholders and stakeholders.
Research conducted by L'Huillier (2014) states that corporate governance can be viewed from a variety of theories so that the point of view and characteristics are varied. This is not much different from most research conducted in Indonesia, although the dominant theory used by corporate governance researchers in Indonesia is Agency Theory, the perspective, and context of corporate governance in Indonesia can be very broad and diverse.

This study refers to a study conducted by Hesford et al. (2007) who conducted a bibliographic study of management and management accounting conducted by Suprianto \& Setiawan (2017) who compiled a study on a bibliography of profit management in Indonesia. The researchers tried to review the definition, proxy, the year of research and the appropriateness of its implementation in Indonesia, considering that Indonesia already has regulations governing corporate governance in Indonesia. This study uses 101 articles on corporate governance from 10 accredited national journals throughout approximately 11 years, i.e., from 2007-2017. Researchers will then conduct an analysis and reclassify the development of corporate governance research over 11 years from several aspects which have been selected.

This research is expected to be able to give contribution and proof that there is still proxy who is not yet in accordance with the implementation of corporate governance in Indonesia as well as a reference for further research in the field of corporate governance.

Table 1. List of Sample Journals

\begin{tabular}{ll}
\hline \multicolumn{1}{c}{ Name of Journal } & \multicolumn{1}{c}{ Institution } \\
\hline Jurnal Akuntansi dan Auditing Indonesia (JAAI) & Universitas Islam Indonesia \\
Jurnal Akuntansi Keuangan Indonesia (JAKI) & Universitas Indonesia \\
Jurnal Akuntansi dan Keuangan (JAK) & Universitas Kristen Petra \\
Jurnal Aplikasi Manajemen (JAM) & Universitas Brawijaya \\
Jurnal Keuangan dan Perbankan (JKP) & University of Merdeka Malang \\
Jurnal Ilmiah Manajemen - MIX & Universitas Mercubuana \\
Jurnal Akuntansi & Universitas Tarumanegara \\
Journal of Business Economics and Accounting - Ventura & STIE Perbanas Surabaya \\
Jurnal Manajemen & Universitas Kristen Petra \\
Jurnal Dinamika Manajemen & Universitas Negeri Semarang \\
\hline
\end{tabular}




\section{Corporate governance in Indonesia: One decade perspective}

Aliffianti Safiria Ayu Ditta \& Doddy Setiawan

\section{Method, Data, and Analysis}

The method used in this study uses charting the fields developed by Hesford et al. (2007). In the charting, the fields approach, the researcher chooses research articles on corporate governance published in 10 journals as presented in Table 1, then grouped by topic, method, and discipline.

The selection of the journal was based on the following criteria: (1) a nationally accredited journal by 2017 ; (2) articles selected in the journal related to corporate governance research in Indonesia; and (3) the journal was possibly accessed online.

\section{Results}

This study used 101 articles obtained from 10 national accredited journals that had met the three criteria as aforementioned. Researchers chose the study period for 11 years, i.e., from 2007-2017 with consideration of the Law on Limited Liability Company article 40 the year 2007 has been ratified, so companies that have legal entities of Limited Liability Company must be obedient and at any time companies undergo changes and adjustments. It also affects the implementation of corporate governance. In addition, the researchers should ensure that during the 2007-
2017, the selected articles are from journals that are in accredited status.

Table 2 presents a sample description that can be viewed in total (from 2007-2017). The percentage of research articles on corporate governance from each journal include Jurnal Akuntansi Keuangan Indonesia (JAKI) as much as 18.81 percent, Journal of Business and Accounting Venture 17.82 percent, Jurnal Akuntansi dan Auditing Indonesia (JAAI) as much as 15.84 percent, Jurnal Akuntansi dan Keuangan (JAK) for 13.86 percent, Jurnal Keuangan dan Perbankan (JKP) 12.87 percent, Jurnal Aplikasi Manajemen (JAM) 9.90 percent, Jurnal Manajemen for 3.96 percent, Jurnal Akuntansi 2.97 percent Jurnal Dinamika Manajemen 2.97 percent, and Jurnal Ilmiah Manajemen - MIX as much as 0.99 percent. There have been several increases in the number of articles published in each accredited journal from 2007-2017.

\section{Discussion \\ Article classification}

Research conducted by Hesford et al. (2007) classifies each article based on topics, methods, and disciplines. In this study, researchers only classified articles based on two classifications, namely by topic and research methods.

Table 2. Sample Description

\begin{tabular}{lrrrrrr}
\hline \multirow{2}{*}{ Name of Journal } & \multicolumn{2}{c}{$\mathbf{2 0 0 7 - 2 0 1 7}$} & \multicolumn{2}{c}{$\mathbf{2 0 0 7 - 2 0 1 2}$} & \multicolumn{2}{c}{$\mathbf{2 0 1 3 - 2 0 1 7}$} \\
\cline { 2 - 6 } & Number & \% & Number & \% & Number & \% \\
\hline JAKI & 19 & 18.81 & 8 & 22.22 & 1 & 16.92 \\
VENTURA & 18 & 17.82 & 5 & 13.89 & 13 & 20.00 \\
JAAI & 16 & 15.84 & 6 & 16.67 & 10 & 15.38 \\
JAK & 14 & 13.86 & 5 & 13.89 & 9 & 13.85 \\
JKP & 13 & 12.87 & 5 & 13.89 & 8 & 12.31 \\
JAM & 10 & 9.90 & 3 & 8.33 & 7 & 10.77 \\
JM & 4 & 3.96 & 4 & 11.11 & 0 & 0.00 \\
JDM & 3 & 2.97 & 0 & 0.00 & 3 & 4.62 \\
JA & 3 & 2.97 & 0 & 0.00 & 3 & 4.62 \\
MIX & 1 & 0.99 & 0 & 0.00 & 1 & 1.54 \\
TOTAL & 101 & & 36 & & 65 \\
\hline
\end{tabular}




\section{Articles classification based on topics of discussion}

The classification of articles on corporate governance if it is based on the topic of discussion is divided into two namely the antecedents (factors that motivate the emergence of corporate governance) and the consequences (impact resulting from corporate governance). Table 3 shows the classification of articles based on antecedent variables and indicate those 37 articles or 36.63 percent of corporate governance emerged due to management behavior. Management as agent roles in the management of resources owned by companies that have been entrusted by the principal. It is proper that management has an awareness and a sense of responsibility in managing these resources, but it is not uncommon for the occurrence of a conflict of interest to make these managers act for their interests. This condition is mentioned in the Agency Theory (Jansen \& Meckling, 1976).

Table 3. Classification of Antecedents Variables

\begin{tabular}{lrr}
\hline \multicolumn{1}{c}{ Antecedent Variable } & \multicolumn{1}{c}{$\%$} \\
\hline Management Behavior & 37 & 36.63 \\
Banking regulation & 10 & 9.90 \\
Ownership structure & 6 & 5.94 \\
Disclosure of CSR & 5 & 4.95 \\
Supervision & 5 & 4.95 \\
Audit quality & 5 & 4.95 \\
Company size & 5 & 4.95 \\
Disclosure and timeliness & 4 & 3.96 \\
Market conditions & 3 & 2.97 \\
Financial Ratio & 2 & 1.98 \\
Company Strategy & 2 & 1.98 \\
Government regulation & 2 & 1.98 \\
Tax regulation & 1 & 0.99 \\
Other & 14 & 13.86 \\
\hline Total & 101 & \\
\hline
\end{tabular}

Source: the result of processed data

Table 4 shows the article classification based on the consequence variable and the company performance results dominate by 39.60 percent or as many as 40 articles. Most of the corporate governance re- searchers in Indonesia state that the implementation of corporate governance in the company will have an impact on the company's performance. Investors will look at corporate performance and governance within the company before deciding to invest, given the unavoidable conflicts of interest between agents and principals, but at least with the implementation of corporate governance, the impact of such conflicts can be minimized.

Table 4. Classification of Consequence Variables

\begin{tabular}{lrr}
\hline \multicolumn{1}{c}{ Consequence Variables } & \multicolumn{1}{c}{$\%$} \\
\hline Company performance & 40 & 39.60 \\
Disclosure of financial statements & 16 & 15.84 \\
Corporate value & 12 & 11.88 \\
Quality of financial statements & 11 & 10.89 \\
Disclosure of CSR & 6 & 5.94 \\
Tax avoidance & 3 & 2.97 \\
Fraud & 3 & 2.97 \\
Disclosure IC & 1 & 0.99 \\
Other & 9 & 8.91 \\
\hline Total & 101 & \\
Source: the result of processed data & \multicolumn{3}{l}{}
\end{tabular}

\section{Articles classification based on research methods}

Classification of articles based on research methods is divided into three methods: survey, analytical and literature review. In Table 5 can be viewed 96 articles or 95.05 percent of corporate governance researches in Indonesia were done by analytical method, 2.97 percent using the survey method and review method as much as 1.98 percent. So the conclusion is the method of corporate governance researches in Indonesia is dominated by analytical methods.

Table 5. Classification by Method

\begin{tabular}{lcc}
\hline \multicolumn{1}{c}{ Method } & Number & \% \\
\hline Analytical & 96 & 95.05 \\
Survey & 3 & 2.97 \\
Review & 2 & 1.98 \\
\hline Total & 101 & 100 \\
\hline Source: the result of processed data &
\end{tabular}


Table 6. Two Tier Disclosure

\begin{tabular}{ccc}
\hline Number of Samples & $\begin{array}{c}\text { Two-Tier Disclosure and Law Number 40 the Year 2007 on Limited } \\
\text { Liability Company }\end{array}$ & $\%$ \\
\hline 101 & 22 & 21.78 \\
\hline
\end{tabular}

\section{Corporate Governance Context in Indonesia}

\section{Law number $\mathbf{4 0}$ the year 2007 on limited liability company and two-tier disclosures}

As shown in Table 6, from 101 articles obtained by the researcher, only 22 articles or 21.78 percent discussed corporate governance in accordance with existing conditions in Indonesia and mentioned that Indonesia embraced two-tier governance that separates functions board of commissioners and board of directors. In Law number 40 year 2007 article 1 it is stated that the Board of Commissioners is the organ of the company which is in charge of supervising in general and/ or specifically in accordance with the articles of association and giving advice to the Board of Directors, while the Board of Directors is the organ of the company authorized and fully responsible for the management of the company for the benefit of the company, in accordance with the purposes and objectives of the company and to represent the company, both inside and outside the court in accordance with the provisions of the articles of association. This implies that Law number 40 the year 2007 confirms that Indonesia adheres to a two-tier system that separates the functions of the board of commissioners and the board of directors. This is different from the concept of the board in countries that follow a one-tier system.

Most of the researches on corporate governance in Indonesia focus only on the existence of the board of commissioners as the key to the implementation of corporate governance, both in the presence of the independent board of commissioners and the size of the board of commissioners within the company. When viewed from its function, the existence of the board of directors also has a role that is not less important in the company and contributes to corporate governance. Moreover, Indonesia is one of the countries that ad- here to the two-tier principles in the implementation of corporate governance, so that both the board of commissioners and the board of directors have a clear separation of functions and important role in the application of corporate governance principles in the company.

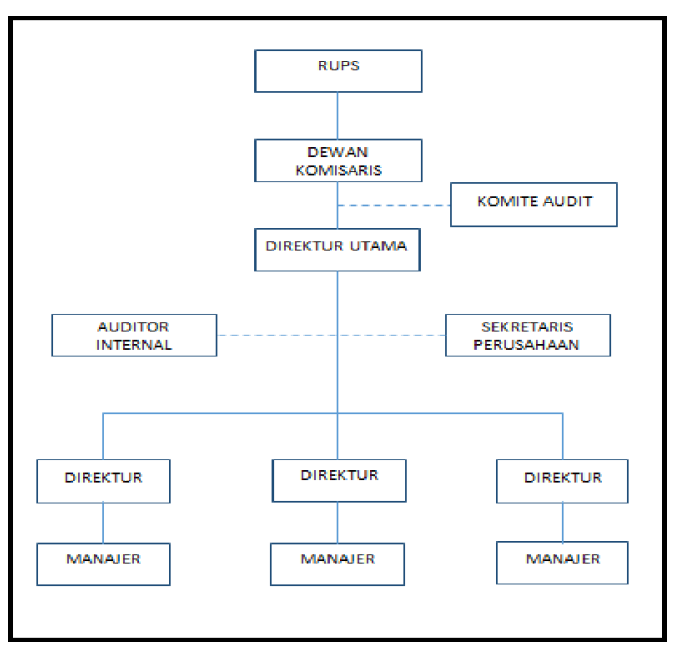

Figure 1. Organization Structure

In Figure 1 it is clearly illustrated that the functions of the board of commissioners and the board of director are separated. The function of the board of commissioners is more on the supervision, and the board of directors leads to the execution. In accordance with Law No. 40 the Year 2007 regarding Limited Liability Company article 1, paragraph 3 , it is clear that the RUPS has the authority that is not given to directors and board of commissioners so that the RUPS has the highest authority in a Limited Liability Company.

\section{Proxy of corporate governance}

If we look at the data presented in Table 7, the most widely used proxy is the audit committee of 
18.45 percent, the proportion of independent commissioners is 17.48 percent, and the size of the board of commissioners is 16.5 percent. The audit committee is the most used proxy by corporate governance researchers in Indonesia considering the duties and functions of an audit committee which are directly related to the supervisory function on financial reporting and internal control. Audit committee proxies are often used given that corporate governance focuses on supervisory functions. The other two most widely used proxies are the proportion of independent commissioners and board of commissioners. The function of the board of commissioners also leads to a supervisory function.

Corporate governance will only lead to a supervisory structure if these three proxies are the most frequently used ones, namely the audit committee, the independent commissioners and the board of commissioners. Corporate governance as a form of good corporate management should be a unified function of each other and not only focus on one function only. If we look at the percentage of proxies that are most widely used, the researches of corporate governance in Indonesia still view the "narrow" scope of corporate governance so that it only refers to the existence of the audit committee, board of commissioners and the proportion of independent commissioners and less discuss the existence of board of directors and other important functions in corporate governance mechanisms.

As mentioned above, Indonesia holds two tiers in the implementation of corporate governance, so that the board of directors has the same role and function as important as the board of commissioners. Board of directors is one of the party who has a responsibility in managing the company in accordance with the objectives owned by the company. Board of directors may act as trustee and agent in a limited liability company. The board of directors is said to be a trustee because the directors are responsible for managing the resources owned by the company and act as an agent because the directors act out for and on behalf of the company.

From the data presented in Table 7, 10.19 percent of the majority of corporate governance research in Indonesia which dealt with managerial ownership and 9.22 percent discussed institutional ownership. In some previous studies, the ownership structure of companies in Indonesia has different characteristics from companies in other countries (Wiranata $\&$ Nugrahanti, 2013). The ownership structure in Indonesia is mostly concentrated in ownership so that the founders of the company can act as a board of directors and commissioners. Agency conflicts that often occur in Indonesia are between majority and minority shareholders, where the majority shareholders who supervise the performance of managers ask managers to make decisions that benefit the majority shareholders so in because it can harm the majority shareholders (Wiranata \& Nugrahanti, 2013). Agency conflict in companies in Indonesia may arise because it is triggered by information asymmetry between agent and principal and conflict between majority and minority shareholders (Amin, 2016).

The majority and minority shareholders, both from management, institutions, and families, the government and foreign parties have a share in the company. Corporate governance is considered to function as a monitoring mechanism to protect shareholders and investors from opportunistic behavior (Djumahir, 2008). Most companies in Indonesia have concentrated ownership tendencies so that the founders of the company can sit as a board of commissioners and board of directors (Wiranata \& Nugrahanti, 2013).

Anderson \& Reeb (2003) state that the company led by the founder has better performance compared to other companies. This is in line with Suprianto \& Setiawan (2018) which show family companies in Indonesia tend to have a higher level of profitability than non-family companies. However, research conducted by Prabowo \& Simpson (2011) shows that family ownership in Indonesia has a negative effect on company performance. This is caused by the weak legal protection of investors in the ownership structure so that it can cause agency problems that can interfere with the company's performance (Claessens et al., 2000; La Porta, Lopez, \& Sheifer, 2000). Research conducted by Setiawan et al. (2016) shows that fam- 


\section{Corporate governance in Indonesia: One decade perspective}

Aliffianti Safiria Ayu Ditta \& Doddy Setiawan

ily ownership in Indonesia has a negative influence on dividend payments. Family companies tend to hold back profits rather than share them with minority shareholders.

One way to reduce agency costs arising from agent and principal conflicts is to increase the shareholding of managers in the company so that their interests are aligned with the interests of shareholders (Jensen \& Meckling, 1976). A total of 10.19 percent of 101 corporate governance articles discussed this managerial ownership. Share ownership by managers can encourage managers to be careful in making decisions because they share both the advantages and disadvantages of what they have decided (Listyani, 2003). The ownership of shares by managers will unite the interests between the agent and the principal so that managers will act in accordance with the wishes of shareholders and this can improve the performance of the company (Bathala, Moon, \& Rao, 1994) although research conducted in Indonesia states that the ownership of shares by managers is not enough to make a difference in performance achievement because some managerial ownership is a minority (Christiawan $\&$ Tarigan, 2007).

The discussion on institutional ownership by corporate governance researchers in Indonesia was 9.22 percent of the 101 articles selected. Institutional ownership is the proportion of share ownership by agencies such as the private sector, NGOs, banks or other investment companies (Wiranata \& Nugrahanti, 2013). Institutional ownership has a positive influence on the company's financial performance because the existence of institutional investors is considered optimal in overseeing every decision taken by the management (Kusumawati, 2007).

In addition to family ownership, managerial and institutional ownership by the government and foreign parties cannot be ignored. Government ownership is the number of share ownership owned by the government from all managed share capital, and the results of the study reveal that government ownership has a negative effect on the company's performance (Wiranata $\&$ Nugrahanti, 2013). This is because the government of- ten has political interests so it does not pay attention to the performance of the company itself.

Foreign ownership in the company is a very obedient and caring party to implement good corporate governance in the company (Simerly \& Li, 2000). Foreign ownership has a positive and significant influence on company performance (Kumar, Subramaian, \& Strandholm, 2004). Foreign ownership is considered to be able to improve the company's performance through investments that have systems and technology that are always upgraded so that it can have a positive influence on the company.

Seeing the important role of shareholders and ownership structure, even as important as the existence of the board of commissioner and directors, the interest of corporate governance researchers in Indonesia to review the implications of corporate governance for both majority and minority shareholders is still insufficient. Of the 101 samples of articles used, only 10.19 percent reviewed managerial ownership, and 9.22 percent reviewed institutional ownership. Whereas when viewed from the agency theory, the ownership structure of a company can affect agency problems in a company (Jensen \& Meckling, 1976). Corporate governance and ownership structure should be used as a consideration for the level of protection for investors who will invest in the company. By applying the principles of corporate governance, it is expected that effective supervision will occur based on the balance of authority between the shareholders, the board of commissioners and the board of directors (Djumahir, 2008).

In addition to the existence of the board of directors of less desirable researchers, the existence of risk management and application of CGPI scores as evaluation of corporate governance implementation by the company is also still little covered on in previous research. It should be remembered that risk management plays an important role in ensuring the realization of corporate governance principles within the company. Risk management can be defined as a process of identifying, assessing and mapping out possible risks that may arise in a company's activities. The objective of 
risk management is to minimize risk and minimize the possibility of losses that will be faced by the company and prepare the company to face the risks that will be encounter so that the amount of risk that will be accepted is still within the limits of the company's ability to accept the risk.

Implementation of risk management within the company should be related to risk management guidelines, principles and methods. These three things must be agreed upon and performed by every component of the company so that risk management within the company can be applied maximally. Risk management is created to help companies to minimize the uncertainty in achieving targeted company goals. Risk management plays an important role to provide protection not only to shareholders but also to internal and external stakeholders.

The percentage of researches in Indonesia using risk management proxy is only 0.49 percent. Since risk is inherent and unavoidable by the company in a business environment full of uncertainty, the existence of a risk management committee is crucial as a component of corporate governance.

The CGPI (Corporate Governance Perception Index) score is a ranking of corporate governance implementation in companies in Indonesia. The rating results using CGPI scores will show the quality of corporate governance implementation with a percentage indicating the level of confidence in the company. CGPI score consists of several items, i.e.: (1) fairness; (2) commitment; (3) leadership; (4) strategy; (5) ethics; (6) vision, mission, values, and force; (7) culture; (8) transparency; (9) accountability; (10) responsibility; and (11) independence (SWA Magazine).

The implementation of corporate governance within the company should always be monitored and evaluated in order to maintain the quality of its implementation and in line with the development of applicable laws and regulations. Ranking with CGPI is one way to evaluate the implementation of corporate governance by self- assessment. Despite applying the self- assessment method, it still adheres to the guidelines and procedures set by some regulators.

The researches on corporate governance in Indonesia using CGPI score as its proxy is only 6.80 percent, and financial companies and banking conducted most of this amount. If we look at the importance of CGPI score for corporate confidence in Indonesia, CGPI score can also be taken into consideration by investors and creditors in investment decision making and lending.

There are interesting things that appear to be presented in Table 7, namely the researches that discuss the duality. CEO duality is the presence of someone who served as CEO and chairman of the board. The existence of a duality CEO allows for centralization forces that may lead to management discretion (Murhadi, 2009). In Indonesia, CEO duality should not be allowed to make corporate supervisory activities more effective to run.

Table 7. Corporate Governance Proxy

\begin{tabular}{lrr}
\hline \multicolumn{1}{c}{ Proxy } & \multicolumn{1}{c}{$\%$} \\
\hline Audit Committee & 38 & 18.45 \\
The proportion of independent & & \\
commissioners & 36 & 17.48 \\
Board of commissionaire size & 34 & 16.50 \\
Managerial Ownership & 21 & 10.19 \\
Institutional ownership & 19 & 9.22 \\
CGPI Score (Corporate Governance & & \\
Perception Index) & 14 & 6.80 \\
Self-assessment composite & 9 & 4.37 \\
Board of directors & 6 & 2.91 \\
Number of the board of commissioners & 5 & 2.43 \\
BPKP instruments consisting of 5 GCG & & \\
indicators & 4 & 1.94 \\
Gender & 4 & 1.94 \\
Duality & 3 & 1.46 \\
Outside director & 2 & 0.97 \\
Age & 2 & 0.97 \\
Executive character & 1 & 0.49 \\
Risk management committee & 1 & 0.49 \\
ASEAN corporate governance scorecard & 1 & 0.49 \\
Boar of commissionaire activeness & 1 & 0.49 \\
Ethnic & 1 & 0.49 \\
Education & 1 & 0.49 \\
Insider & 1 & 0.49 \\
Likert scale & 1 & 0.49 \\
Auditor reputation & 1 & 0.49 \\
\hline
\end{tabular}




\section{Corporate governance in Indonesia: One decade perspective}

Aliffianti Safiria Ayu Ditta \& Doddy Setiawan

\section{The range of years of research}

As listed in Table 8, the average corporate governance research in Indonesia was conducted for 3.46 years. A short period is less able to represent the quality of corporate governance in Indonesia. Some companies even replace the board of commissioners or directors after five years in office or accordance with the resolutions of the RUPS. In short the period of the study, it will be difficult to evaluate the quality of corporate governance applied to each sample in the article.

Table 8. Number of years of research

\begin{tabular}{cc}
\hline Number of Samples & $\begin{array}{c}\text { The Average of the } \\
\text { Research Year }\end{array}$ \\
\hline 101 & 3.46 \\
\hline
\end{tabular}

\section{Conclusion, Limitations, and Suggestions Conclusion}

Researches on corporate governance in Indonesia still view the "narrow" corporate governance. Corporate governance should be viewed in the context of its application in Indonesia. This can be seen from the lack of two-tier disclosure in existing studies, and not only use one component that has always been dominantly used in several studies. The commonly used proxies are audit committee as much as 18.45 percent, the proportion of independent commissioners is 17.48 percent, and the size of the board of commissioners is 16.50 percent. This shows that corporate governance research in Indonesia still views the supervisory function as an important element of the success of corporate governance in companies in Indonesia, thus impressing other corporate governance aspects such as the existence of the board of directors, risk management committee, assessment of corporate gov- ernance using score of Corporate Governance Perception Index (CGPI) as well as the importance of corporate governance in terms of shareholders and their ownership structure. In Indonesia, it is not possible to have duality CEO within the company, as it would be contrary to the prevailing regulation in Indonesia which is Law No. 40 of 2007 on Limited Liability Company, so if there is any research in Indonesia that brings up the duality CEO, it is not appropriate to be applied in Indonesia.

\section{Limitations and suggestions}

This research still has some limitations, such as an analytical method which still dominates corporate governance research method in Indonesia, so it is possible for the next researcher to use survey and review method in reviewing the existence of corporate governance in Indonesia. Corporate governance proxies that only focus on the supervisory function, so that further research is expected to use other corporate governance proxies that are no less important as corporate governance proxies are often used for more than a decade, especially corporate governance when viewed from the side of shareholders parties who have important positions such as board of commissioners and board of directors.

In this study also touched on the shortness of time range of corporate governance research so that further research is expected to use a longer timeframe to assess the quality of corporate governance implementation in a company in Indonesia. Further research that will discuss corporate governance in Indonesia is expected to discuss the two-tier system to get the understanding that there is a clear difference between countries that apply the one-tier system and two-tier system. 


\section{References}

Achmad, T. (2012). Dewan komisaris dan transparansi: Teori keagenan atau teori stewardship? Jurnal Keuangan dan Perbankan, 16(1), 1-12. http://jurnal.unmer.ac.id/index.php/jkdp/article/view/1041

Adnan, M. A., Gunawan, B., \& Candrasari, R. (2014). Pengaruh profitabilitas, leverage, growth, dan free cash flow terhadap dividend payout ratio perusahaan dengan mempertimbangkan corporate governance sebagai variabel intervening. Jurnal Akuntansi dan Auditing Indonesia, 18(2), 89-100. https://doi.org/10.20885/jaai.vol18.iss2.art1

Agusti, R., R., \& Rahman, A. F. (2011). Relevansi informasi akuntansi: Peran pengungkapan corporate social responsibility dan dewan komisaris independen. Jurnal Akuntansi dan Auditing Indonesia, 15(2), 121-129.

Agustia, D. (2013). Pengaruh faktor good corporate governance, free cash flow, dan leverage terhadap manajemen laba. Jurnal Akuntansi dan Keuangan, 15(2), 27-42. https://doi.org/10.9744/jak.15.1.27-42

Akmyga, S. F., \& Mita, A. F. (2015). Pengaruh struktur corporate governance dan kualitas audit terhadap luas pengungkapan kompensasi manajemen kunci di laporan keuangan. Jurnal Akuntansi dan Keuangan Indonesia, 12(1), 19-36. https://doi.org/10.21002/jaki.2015.02

Amertha, I. S., Ulupui, I. G. K. A., \& Putri, I. G. A. M. (2014). Analysis of firm size, leverage, corporate governance on earnings management practices (Indonesian evidence). Journal of Economics, Business, and Accountancy Ventura, 17(2), 259-268. https://doi.org/10.14414/jebav.14.1702009

Amin, A. (2016). Independensi komite audit, kualitas audit, dan kualitas laba: Bukti empiris perusahaan dengan kepemilikan terkonsentrasi. Jurnal Akuntansi dan Keuangan, 18(1), 1-14. https://doi.org/10.9744/jak.18.1.114

Anafiah, V. A., Diyanti, V., \& Wardhani, R. (2017). The effect of controlling shareholders and corporate governance on audit quality. Jurnal Akuntansi dan Keuangan Indonesia, 14(1), 1-19. https://doi.org/10.21002/jaki.2017.01

Andarini, P., \& Januarti, I. (2012). Hubungan karakteristik dewan komisaris dan perusahaan terhadap keberadaan komite manajemen risiko pada perusahaan go public Indonesia. Jurnal Akuntansi dan Kenangan Indonesia, 9(2), 83-99. https://doi.org/10.21002/jaki.2012.06

Anderson, R. C., \& Reeb, D. M. (2003). Founding family ownership, corporate diversification, and firm leverage. The Journal of Law and Economics, 46(2), 653-684. https://doi.org/10.1086/377115

Andriyan, O., \& Supatmi. (2010). Pengaruh mekanisme corporate governance terhadap kinerja keuangan bank perkreditan rakyat. Jurnal Akuntansi dan Keuangan Indonesia, 7(2), 187-214. https://doi.org/10.21002/ jaki.2010.11

Anggraeni, D. Y., \& Djakman, C. D. (2017). Slack resources, feminisme dewan, dan kualitas pengungkapan tanggung jawab sosial perusahaan. Jurnal Akuntansi dan Keuangan Indonesia, 14(1), 94-118. https://doi.org/10.21002/ jaki.2017.06

Aprinthia, B. S. (2016). Pengaruh good corporate governance terhadap kinerja keuangan pada perusahaan sektor consumer goods yang terdaftar di Bursa Efek Indonesia tahun 2012-2014. Jurnal Bisnis dan Manajemen, 52(11), 32-53. https://journal.untar.ac.id/index.php/bm/article/view/719

Arifah, D. A. (2012). Pengaruh mekanisme corporate governance terhadap pengungkapan intellectual capital pada perusahaan IC Intensive. Jurnal Akuntansi dan Keuangan Indonesia, 9(2), 189-211. https://doi.org/10.21002/ jaki.2012.12

Atmini, S. (2011). Pengaruh mekanisme corporate governance terhadap innate accrual quality dan discretional accruals quality. Jurnal Aplikasi Manajemen, 9(3), 785-797. 


\section{Corporate governance in Indonesia: One decade perspective}

Aliffianti Safiria Ayu Ditta \& Doddy Setiawan

Bathala, C. T., Moon K. P., \& Rao, R. P. (1994). Managerial ownership, debt policy, and the impact of institutional holdings: An agency perspective. Financial Management, 23, 38-50. https://doi.org/10.2307/3665620

Bhat, P. R., \& Bhatt, R. R. (2017). Corporate governance and firm performance in Malaysia. The International Journal of Business in Society, 17(5), 896-912. https://doi.org/10.1108/CG-03-2016-0054

Butar Butar, S. (2014). Implikasi regulasi pasar modal terhadap motif manajemen laba: Pengujian berbasis teori pensinyalan. Jurnal Akuntansi dan Keuangan Indonesia, 11(1), 99-119. https://doi.org/10.21002/jaki.2014.06

Caesari, A. P., Irwanto, A. K., \& Syamsun, M. (2016). Analisis hubungan corporate governance, corporate social responsibility, dan corporate financial performance pada Perusahaan Kompas 100. Jurnal Aplikasi Manajemen, 14(1), 78-87. https://doi.org/10.18202/jam23026332.14.1.09

Cahyaningtyas, S. R., Sasanti, E. E., \& Husnaini, W. (2017). Bank risk profile, good corporate governance, and firm values in go public banking companies in Indonesia. Journal of Economics, Business, and Accountancy Ventura, 20(1), 41-46. https://doi.org/10.14414/jebav.v20i1.759

Christiawan, Y. G., \& Tarigan, J. (2007). Kepemilikan manajeral: Kebijakan hutang, kinerja dan nilai perusahaan. Jurnal Akuntansi dan Keuangan, 9(1), 1-8. https://doi.org/10.9744/jak.9.1.1-8

Claesens, S., Djankov, S., Fan, J. P. H., \& Lang, L. H. P. (2000). The separation of ownership and control in East Asian corporation. Journal of Financial Economics, (58), 81-112. https://doi.org/10.106/S0304-405X(00)00067-2

Damayanti, D. D., \& Chaniagon, H. (2014). Pengaruh risiko usaha dan good corporate governance terhadap skor kesehatan bank pada bank umum swasta nasional devisa. Journal of Business and Banking, 4(2), 217-230. https:/ /doi.org/ 10.14414/jbb.v4i2.373

Darwis, H. (2012). Manajemen laba terhadap nilai perusahaan dengan corporate governance sebagai pemoderasi. Jurnal Keuangan dan Perbankan, 16(3), 45-55. Retrieved from: http://jurnal.unmer.ac.id/index.php/jkdp/article/view/1045

Dewany, W. F. (2015). Analysis of the effect of corporate governance quality on the financial performance of Islamic banks. The Indonesian Accounting Review, 5(2), 119-128. https://doi.org/10.14414/tiar.v5i2.560

Dewi, N. H. (2012). Corporate governance in the effort of increasing the company's Value. Journal of Economics, Business, and Accountancy Ventura, 15(2), 331-342. https://doi.org/10.14414/jebav.v15i2.84

Djumahir. (2008). Pengaruh good corporate governance dan kepemilikan manajemen terhadap kinerja manajemen (studi pada industri automotive di BEI). Jurnal Aplikasi Manajemen, 9(1), 20-28.

Dwiharyadi, A. (2017). Pengaruh keahlian akuntansi dan keuangan komite audit dan dewan komisaris terhadap manajemen laba. Jurnal Akuntansi dan Keuangan Indonesia, 14(1), 75-93. https://doi.org/10.21002/jaki.2017.05

Ekaputri, C. (2014). Tata kelola, kinerja rentabilitas, dan risiko pembiayaan perbankan syaria. Journal of Business and Banking, 4(1), 91-104. https://doi.org/ 10.14414/jbb.v4i1.296

Fadah, I. (2013). Pengaruh dividen dan biaya keagenan terhadap nilai perusahaan (model komparatif pada perusahaan yang menerapkan corporate governance dengan intensitas tinggi dan rendah. Jurnal Aplikasi Manajemen, 11(2), 223-232.

Fanani, Z. (2014). Karakteristik perusahaan dan corporate governance terhadap manajemen laba: Studi analisis meta. Jurnal Keuangan dan Perbankan, 18(2), 181-200. Retrieved from: http://jurnal.unmer.ac.id/index.php/jkdp/ article/view/791

Gumanti, T. A., \& Prasetiawati, W. (2011). Board of commisioner duality role, governance and earnings management of initial public offerings in Indonesia. Jurnal Akuntansi dan Kenangan, 13(2), 80-86. https://doi.org/10.9744/ jak.13.2.80-86 
Habiba. (2016). The effect of good corporate governance mechanism and leverage on the level of accounting conservatism. The Indonesian Accounting Review, 6(1), 67-80. https://doi.org/10.14414/tiar.v6i1.572

Hanggara, K. (2016). Pengaruh corporate governance terhadap manajemen laba (studi empiris pada perusahaan manufaktur yang terdaftar di Bursa Efek Indonesia pada tahun 2010-2012). Jurnal Bisnis dan Manajemen, 53(2), 110-126.

Hendro, \& Wardhani, R. (2015). Pengaruh agency cost of free cash flow terhadap tingkat konservatisme dan pengujian efek moderasi kebijakan hutang, pendistribusian kas, persistensi kas, dan tata kelola perusahaan. Jurnal Akuntansi dan Keuangan, 17(1), 41-56. https://doi.org/10.9744/jak.17.1.41-56

Herawaty, V. (2008). Peran praktek corporate governance sebagai moderating variable dari pengaruh earnings management terhadap nilai perusahaan. Jurnal Akuntansi dan Keuangan, 10(2), 97-108. https://doi.org/10.9744/ jak. 10.2.97-108

Herusetya, A. (2009). Efektifitas pelaksanaan corporate governance dan audit eksternal-auditor dengan spesialisasi industri dalam menghambat manajemen laba. Jurnal Akuntansi dan Auditing Indonesia, 13(2), 167-188. Retrieved from: https://journal.uii.ac.id/JAAI/article/view/2268

Hesford, J. W., Lee, S. H., Van der Stede, W. A., \& Young, S. M. (2007). Management Accounting: A Bibliographic Study. Handbook of Management Accounting Research. Elsevier Ltd.

Hidayah, E. (2008). Pengaruh kualitas pengungkapan informasi terhadap hubungan antara penerapan coroporate governance dengan kinerja perusahaan di Bursa Efek Jakarta. Jurnal Akuntansi dan Auditing Indonesia, 12(1), 53-64. Retrieved from: https://journal.uii.ac.id/JAAI/article/view/36

Hidayati, N., \& Sunaryo, H. (2016). Dampak corporate governance terhadap keputusan dividen (literature review pada negara-negara di Asia, Australia, dan Afrika). Jurnal Kenangan dan Perbankan, 20(1), 32-41. Retrieved from: http://jurnal.unmer.ac.id/index.php/jkdp/article/view/146

Istiqomah, A., \& Adhariani, D. (2017). Pengaruh manajemen laba terhadap stock return dengan kualitas audit dan efektivitas komite audit sebagai variabel. Jurnal Akuntansi dan Keuangan, 19(1), 1-12. https://doi.org/10.9744/ jak.19.1.1-12

Istorini, L. T., \& Handoyo, S. (2014). Karakteristik dewan komisaris, karakteristik perusahaan, dan keberadaan risk management committee. Jurnal Keuangan dan Perbankan, 18(2), 201-201. Retrieved from: http:// jurnal.unmer.ac.id/index.php/jkdp/article/view/795

Jensen, M. C., \& Meckling, W.H. (1976). Theory of the firm: Managerial behavior, agency cost, and ownership structure. Journal of Financial Economics, 3, 305-360. https://doi.org/10.1016/0304-405X(76)90026-X

Juniarti, \& Sentosa, A. A. (2009). Pengaruh good corporate governance, voluntary disclosure terhadap biaya hutang (costs of debt). Jurnal Akuntansi dan Keuangan, 11(2), 88-100. https://doi.org/10.9744/jak.11.2.88-100

Juniarti. (2013). Good corporate governance and predicting financial distress using logistic and probit regression model. Jurnal Akuntansi dan Keuangan, 15(1), 43-50. https://doi.org/10.9744/jak.15.1.43-50

Kholid, M. N., \& Bachtiar, A. (2015). Good corporate governance dan kinerja maqasid syariah bank syariah di Indonesia. Jurnal Akuntansi dan Auditing Indonesia, 19(2), 126-136. https://doi.org/10.20885/jaai.vol19.iss2.art4

Krismiaji, \& Aryani, Y. A. (2014). The impact of enterprise resource planning and audit committee on accounting information quality. Jurnal Akuntansi dan Auditing Indonesia, 18(1), 65-74. https://doi.org/10.20885/ jaai.vol18.iss1.art5

Krisna, A. D., \& Suhardianto, N. (2016). Faktor-faktor yang mempengaruhi pengungkapan tanggung jawab sosial. Jurnal Akuntansi dan Keuangan, 18(2), 119-128. https://doi.org/10.9744/jak.18.2.119-128 


\section{Corporate governance in Indonesia: One decade perspective}

Aliffianti Safiria Ayu Ditta \& Doddy Setiawan

Krissanti, K., \& Atahu, A. D. (2010). The influence of implementing corporate governance principles towards corporate financial performance in banking sector. Journal of Economics, Business, and Accountancy Ventura, 13(2), 165-174. https://doi.org/10.14414/jebav.v13i2.414

Kumar, K., Subramaian, R., \& Strandholm. K. (2004). Competitive strategy, environtmental scanning, and performance: A content specific analysis of their relationship. International Journal of Commerce and Management, 11(1), 1-33. https://doi.org/10.1108/eb047413

Kusmayadi, D. (2012). Determinasi audit internal dalam mewujudkan good corporate governance serta implikasinya pada kinerja bank. Jurnal Keuangan dan Perbankan, 16(1), 147-156. Retrieved from: http://jurnal.unmer.ac.id/ index.php/jkdp/article/view/1054

Kusumastuti, S., Supatmi, \& Sastra, P. (2007). Pengaruh board diversity terhadap nilai perusahaan dalam perspektif corporate governance. Jurnal Akuntansi dan Keuangan, 9(2), 88-98. https://doi.org/10.9744/jak.9.2.88-98

Kusumawati, D. N. (2007). Profitability and corporate governance disclosure: An Indonesian study. Indonesian Journal of Accounting Research, 10(2), 131-146.

Kusumawati, S. M., \& Hermawan A. A. (2013). The influence of board of commissioners and audit committee effectiveness, ownership structure, bank monitoring, and firm life cycle on accounting fraud. Jurnal Akuntansi dan Keuangan Indonesia, 10(1), 20-39. https://doi.org/10.21002/jaki.2013.02

La Porta, R., Lopez, D. S. F., \& Sheifer A. (1999). Ownership around the world. The Journal of Finance, 54(2), $471-516$. https://doi.org/10.1111/0022-1082.00115

Laela, S. F. (2012). Kualitas laba dan corporate governance: benarkah kualitas laba bank syariah lebih rendah dari bank konvensional? Jurnal Akuntansi dan Keuangan Indonesia, 9(1), 22-42. https://doi.org/10.21002/jaki.2012.02

Lasmanah, \& Yuniar, C. R. (2017). The influence of the mechanism of good corporate governance and capital structure on value of firm in banking sub sector that went public in IDX in 2010-2014. Jurnal Aplikasi Manajemen, 15(2), 280-289. https://doi.org/10.18202/jam23026332.15.2.12

Listyani, T. T. (2003). Kepemilikan manajerial dan pengaruhnya terhadap kepemilikan saham institusional. Jurnal Politeknik Semarang, (3).

L'Huillier, B. M. (2014). What does corporate governance actually mean? Corporate Governance, 14(3), 300-319. https://doi.org/10.1108/CG-10-2012-0073

Lutfi, Silvy, M., \& Iramani, Rr. (2014). The role of board of commissioners and transparency in improving bank operational efficiency and profitability. Journal of Business and Banking, 17(1), 81-90. https://doi.org/10.14414/ jebav.14.170108

Mai, M. U. (2015). Corporate governance dan interdepedensi antara leverage, profitabilitas, serta kebijakan deviden dalam mencapai nilai perusahaan. Jurnal Keuangan dan Perbankan, 19(2), 213-225. Retrieved from: http:// jurnal.unmer.ac.id/index.php/jkdp/article/view/844

Majidi, L. M. (2009). Penguasaan "blockholder" dan reputasi perusahaan di indonesia mencangkup studi eksploratif: Peranan nilai spiritualitas terhadap corporate governance, reputasi perusahaan dan kinerja perusahaan kelompok LQ 45, periode 2006-2007. Jurnal Aplikasi Manajemen, 7(2), 511-520.

Maraya, A. D., \& Yendrawati, R. (2016). Pengaruh corporate governance dan corporate social responsibility disclosure terhadap tax avoidance: Studi empiris pada perusahaan tambang dan CPO. Jurnal Akuntansi dan Auditing Indonesia, 20(2), 147-159. https://doi.org/ doi: 10.20885/jaai.vol20.iss2.art7

Miqdad, M. (2012). Praktik tata kelola perusahaan (corporate governance) dan usefulness informasi akuntansi (telaah teoritis dan empiris). Jurnal Manajemen dan Kewirausahaan, 14(2), 147-155. https://doi.org/10.9744/ jmk.14.2.147-155 
Muktiyanto, A. (2011). Pengaruh interdependensi mekanisme corporate governance terhadap kinerja perbankan. Jurnal Akuntansi dan Keuangan Indonesia, 8(2), 197-213. https://doi.org/10.21002/jaki.2011.12

Murhadi, W. R. (2009). Studi pengaruh good corporate governance terhadap praktik earnings management pada perusahaan terdaftar di PT Bursa Efek Indonesia. Jurnal Manajemen dan Kewirausahaan, 11(1), 1-10. https:// doi.org/10.9744/jmk.11.1.pp.\%201-10

Mursalim. (2009). Persamaan struktural: Aktivisme institusi, kepemilikan institusional dan manajerial, dan kebijakan dividen dan utang. Jurnal Akuntansi dan Auditing Indonesia, 13(1), 43-59. https://journal.uii.ac.id/JAAI/article/ view/2239

Mutmainah, N., \& Wardhani, R. (2013). Analisis dampak kualitas komite audit terhadap kualitas laporan keuangan perusahaan dengan kualitas audit sebagai variabel moderasi. Jurnal Akuntansi dan Keuangan Indonesia, 10(2), 147-170. https://doi.org/10.21002/jaki.2013.08

Nalitami, D. K. (2012). Reaksi pasar atas pengumuman corporate Governance Perception Index pada perusahaan yang terdaftar di Bursa Efek Indonesia. Journal of Business and Banking, 2(2), 199-212. https://doi.org/10.14414/ jbb.v2i2.174

Nandaria, D., \& Kusuma, H. (2015). Pengaruh intellectual capital dan corporate governance terhadap business performance: Pendekatan persamaan struktural. Jurnal Akuntansi dan Auditing Indonesia, 18(1), 16-33. https:/ /doi.org/10.20885/jaai.vol18.iss1.art2

Nisasmara, P. W., \& Musdholifah. (2016). Cash holding, good corporate governance, and firm value. Jurnal Dinamika Manajemen, 7(2), 117-128. https://doi.org/10.15294/jdm.v7i2.8196

Nurim, Y., Sunardi, \& Raharti, R. (2017). The type I versus type II agency conflict on earnings management. Jurnal Dinamika Manajemen, 8(1), 44-58. https://doi.org/10.15294/jdm.v8i1.10410

Nuryaman. (2009). Pengaruh konsentrasi kepemilikan, ukuran perusahaan, dan mekanisme corporate terhadap pengungkapan sukarela. Jurnal Akuntansi dan Keuangan Indonesia, 6(1), 89-116. http://dx.doi.org/10.21002/ jaki.2009.05

Oktaviana, H. (2016). Pengaruh struktur modal, ukuran perusahaan, dan corporate governance terhadap kinerja perusahaan pada perusahaan manufaktur yang terdaftar di Bursa Efek Indonesia. Jurnal Bisnis dan Manajemen, 53(12), 254-284. Retrieved from: https://journal.untar.ac.id/index.php/bm/article/view/745

Pertiwi, T. K., \& Pratama, F. M. (2012). Pengaruh kinerja keuangan and good corporate governance terhadap nilai perusahaan food and beverage. Jurnal Manajemen dan Kewirausahaan, 14(2), 118-127. https://doi.org/10.9744/ jmk.14.2.118-127

Prabowo, M. A., \& Simpson, J. (2011). Independent directors and firm performance in family controlled firms: Evidence from Indonesia. Asian-Pacific Economic Literature, 25(1), 121-132. https://doi.org/10.1108/PAR-072016-0070

Pratiwi, A., Nurkholis, \& Ghofar, A. (2015). Pengaruh corporate governance dan struktur kepemilikan terhadap asimetri informasi. Jurnal Akuntansi dan Auditing Indonesia, 19(2), 99-111. https://doi.org/10.20885/ jaai.vol19.iss2.art2

Praptiningsih, M. (2009). Corporate governance and performance of banking firms: Evidence from Indonesia, Thailand, Philippines, and Malaysia. Jurnal Manajemen dan Kewirausahaan, 11(1), 94-108. https://doi.org/10.9744/ jmk.11.1.\%2094-108

Probohudono, A. N., Perwitasari, D., \& Putra, R. F. (2016). Faktor-faktor yang mempengaruhi remunerasi direksi: studi komparasi perusahaan di Australia, Singapura, Indonesia, dan Malaysia. Jurnal Akuntansi dan Keuangan Indonesia, 13(1), 52-69. https://doi.org/10.21002/jaki.2016.03 


\section{Corporate governance in Indonesia: One decade perspective}

Aliffianti Safiria Ayu Ditta \& Doddy Setiawan

Pujianingsih, S. \& Utami, H. (2011). Good corporate governance terhadap pengungkapan sosial dan kinerja operasi perusahaan dalam Sri-kehati Index. Jurnal Keuangan dan Perbankan, 15(2), 168-177. Retrieved from: http:// jurnal.unmer.ac.id/index.php/jkdp/article/view/1012

Putri, A. K., Sudarma, M., \& Purnomosidhi, B. (2016). Pengaruh corporate social responsibility terhadap nilai perusahaan dengan ukuran perusahaan dan jumlah dewan komisaris sebagai variabel pemoderasi (studi pada perusahaan manufaktur yang terdaftar Bursa Efek Indonesia). Jurnal Aplikasi Manajemen, 14(2), 344-358. https://doi.org/ 10.18202/jam23026332.14.2.16

Republik Indonesia. (2007). Undang-Undang No.40 Tahun 2007 Tentang Perseroan Terbatas. Lembaran Negara RI Tahun 2007, No. 4756. Jakarta: Sekretariat Negara.

Restuningsih, N. (2010). Mekanisme corporate governance dan pengungkapan tanggung jawab sosial terhadap koefisien respon laba. Jurnal Keuangan dan Perbankan, 14(3), 377-390. Retrieved from: http://jurnal.unmer.ac.id/ index.php/jkdp/article/view/980

Ridloah, S. (2016). A qualitative analysis into the strategic priorities of the Indonesian bank industry. Jurnal Dinamika Manajemen, 7(1), 91-105. Retrieved from: https://journal.unnes.ac.id/nju/index.php/jdm/article/view/5762

Rini. (2014). The effect of audit committee role and sharia supervisory board role on financial reporting quality at islamic banks In Indonesia. Journal of Economics, Business, and Accountancy Ventura, 17(1), 145-156. https:// doi.org/10.14414/jebav.14.170113

Rusmin. (2010). Auditor quality and discretionary accruals: Case of Australian listed companies. Jurnal Akuntansi dan Auditing Indonesia, 14(1), 1-27. Retrieved from: https://journal.uii.ac.id/JAAI/article/view/2243

Sabbaghi, O. (2016). Corporate governance in China: A review. Corporate Governance: The International Journal of Business in Society, 16(5), 866-882. https://doi.org/10.1108/CG-12-2015-0162

Sandy, S., \& Lukviarman, N. (2015). Pengaruh corporate governance terhadap tax avoidance: Studi empiris pada perusahaan manufaktur. Jurnal Akuntansi dan Auditing Indonesia, 19(2), 85-98. https://doi.org/10.20885/ jaai.vol19.iss2.art1

Saputra, M. F., Rifa, D., \& Rahmawati, N. (2015). Pengaruh corporate governance, profitabilitas, dan karakter eksekutif terhadap tax avoidance pada perusahaan yang terdaftar di BEI. Jurnal Akuntansi dan Auditing Indonesia, 19(1), 1-12. https://doi.org/10.20885/jaai.vol19.iss1.art1

Sari, A. R., Sutrisno, \& Sukoharsono, E. G. (2013). Pengaruh kepemilikan institusional, komposisi dewan komisaris, kinerja perusahaan terhadap luas pengungkapan corporate social responsibility di dalam sustainability report pada perusahaan manufaktur yang terdaftar di BEI. Jurnal Aplikasi Manajemen, 11(3), 481-491.

Savitri, E. (2016). Good corporate governance memoderasi pengaruh audit manajemen terhadap kinerja manajerial (studi empiris pada perusahaan perbankan di Pekanbaru). Jurnal Aplikasi Manajemen, 14(3), 528-536. https:/ /doi.org/10.18202/jam 23026332.14.3.13

Sayidah, N. (2007). Pengaruh kualitas corporate governance terhadap kinerja perusahaan publik (Studi kasus peringkat 10 besar corporate governance tahun 2003, 2004, 2005). Jurnal Akuntansi dan Auditing Indonesia, 11(1), 1-19. https://journal.uii.ac.id/JAAI/article/view/380

Setiawan, D., Bandi, B., Phua, L. K., \& Trinugroho, I. (2016). Ownership structure and dividend policy in Indonesia. Journal of Asia Business Studies, 10(3), 230-252. https://doi.org/10.1108/JABS-05-2015-0053

Setiawan, L., \& Fitriany. (2011). Pengaruh workload dan spesialisasi auditor terhadap kualitas audit dengan kualitas komite audit sebagai variabel pemoderasi. Jurnal Akuntansi dan Keuangan Indonesia, 8(1), 36-53. https:// doi.org/10.21002/jaki.2011.03

Siahaan, F. (2013). Peran praktek corporate governance memediasi pengaruh struktur kepemilikan terhadap kinerja perusahaan. Jurnal Aplikasi Manajemen, 11(2), 207-214. 
Simerly, R., \& Li, M. (2000). Environmental dynamism, capital structure, and performance: A theoretical integration and an empirical test. Strategic Management Journal, 21, 31-49. https://doi.org/10.1002/(SICI)10970266(200001)

Sirait, H. (2012). Corporate governance practices, share ownership structure, and size on earning management. Journal of Economics, Business, and Accountancy Ventura, 15(1), 145-156. https://doi.org/10.14414/ jebav.v15i1.67

Soleman, R. (2013). Pengaruh pengendalian internal dan good corporate governance terhadap pencegahan fraud. Jurnal Akuntansi dan Auditing Indonesia, 17(1), 53-74. https://doi.org/10.20885/jaai.vol17.iss1.art5

Solikhah, B., \& Winarsih, A. M. (2016). Pengaruh liputan media, kepekaan industri, dan struktur tata kelola perusahaan terhadap kualitas pengungkapan lingkungan. Jurnal Akuntansi dan Keuangan Indonesia, 13(1), 1-22. https:// doi.org/10.21002/jaki.2016.01

Subhan, M., \& Deviyanti, D. R. (2017). Implementasi corporate governance terhadap kinerja sosial perusahaan tambang batu bara pada masyarakat lokal. Jurnal Akuntansi dan Kenangan, 19(1), 48-58. https://doi.org/ doi: 10.9744/jak.19.1.48.58

Sugiono, R., Budiyanto, A., \& Hudiwinarsih, G. (2015). The effect of corporate governance and firm size on company's financial performance. The Indonesian Accounting Review, 5(1), 63-76.

Sugiri, S., Febrianto, R., \& Kresnawati, E. (2017). Sticky cost behavior of bank's executive compensation in four South East Asian countries. Journal of Economics, Business, and Accountancy Ventura, 19(3), 363-376. https://doi.org/ 10.14414/jebav.v19i3.771

Suhardjanto, D. \& Dewi, A. (2011). Pengungkapan risiko finansial dan tata kelola perusahaan: Studi empiris perbankan Indonesia. Jurnal Keuangan dan Perbankan, 15(1), 105-118. Retrieved from: http://jurnal.unmer.ac.id/index.php/ $\mathrm{jkdp} /$ article/view/1005

Suherman, Pardede, Y. Y. P., \& Mardiyati, U. (2016). Pengaruh kinerja perusahaan, corporate governance, dan karakteristik eksekutif terhadap kompensasi eksekutif. Jurnal Kenangan dan Perbankan, 20(1), 1-9. Retrieved from: http://jurnal.unmer.ac.id/index.php/jkdp/article/view/138

Suprianto, E. \& Setiawan, D. (2017). Manajemen laba di Indonesia: Studi sebuah bibliographi. Jurnal Keuangan dan Perbankan, 21(2), 287-301. https://doi.org/10.26905/jkdp.v21i2.1314

Suprianto, E., \& Setiawan, D. (2018). Impact of family control on the relationship between earning management and future performance in Indonesia. Business and Economic Horizons, 14(2), 342-354. https://doi.org/10.15208/ beh.2018.25

Suripto, B. (2014). Determinan pengungkapan informasi atribusi dan dampaknya terhadap persistensi laba. Jurnal Akuntansi dan Keuangan Indonesia, 11(1), 78-98. https://doi.org/10.21002/jaki.2014.05

Suyono, E. (2016). Family controlled firm, governance mechanisms, and corporate performance: Evidence from Indonesia. Journal of Economics, Business, and Accountancy Ventura, 19(1), 111-124. https://doi.org/10.14414/ jebav.v19i1.528

Taufik. (2016). Mediasi profitabilitas pada hubungan antara good corporate governance dan firm size terhadap corporate social responsibility. Mix-Jurnal Ilmiah Manajemen, 6(3), 399-415. Retrieved from: http:// publikasi.mercubuana.ac.id/index.php/Jurnal_Mix/article/view/1279

Tjondro, D., \& Wilopo, R. (2011). Pengaruh good corporate governance terhadap profitabilitas dan kinerja saham perusahaan perbankan yang tercatat di Bursa Efek Indonesia. Journal of Business and Banking, 1(1), 1-14. https://doi.org/10.14414/jbb.v1i1.148 


\section{Corporate governance in Indonesia: One decade perspective}

Aliffianti Safiria Ayu Ditta \&o Doddy Setiawan

Utama, C.A. (2015). Penentu besaran transaksi pihak berelasi: Tata kelola, tingkat pengungkapan, dan struktur kepemilikan. Jurnal Akuntansi dan Keuangan Indonesia, 12(1), 37-54. https://doi.org/10.21002/jaki.2015.03

Utami, H., \& Diyanty, V. (2015). Pengaruh entrenchment effect terhadap kualitas audit dan peran efektifitas komite audit. Jurnal Akuntansi dan Auditing Indonesia, 19(2), 137-152. https://doi.org/10.20885/jaai.vol19.iss2.art5

Uzliawati, L. (2015). Dewan komisaris dan intellectual capital disclosure pada perbankan di Indonesia. Jurnal Keuangan dan Perbankan, 19(2), 226-234. Retrieved from: http://jurnal.unmer.ac.id/index.php/jkdp/article/view/845

Wardhani, R. (2007). Mekanisme corporate governance dalam perusahaan yang mengalami permasalahan keuangan. Jurnal Akuntansi dan Keuangan Indonesia, 4(2), 95-114. https://doi.org/10.21002/jaki.2007.05

Wardhani, R. (2015). Risiko ekspropriasi oleh pemilik pengendali dan tata kelola perusahaan terhadap tingkat penggunaan utang bank. Jurnal Keuangan dan Perbankan. 19(2), 200-212. https://doi.org/ jurnal.unmer.ac.id/ index.php/jkdp/article/view/843

Wardhani, R. (2015). The role of investor protection in corporate governance and accounting harmonization: Crosscountry analysis in Asia. Journal of Economics, Business, and Accountancy Ventura. 18(2), 267-282. https:// doi.org/10.14414/jebav.v18i2.453

Wedari, L. K. (2015). Aktivitas Komite Audit, Kepemilikan Institusional dan Biaya Audit”, Jurnal Akuntansi dan Keuangan. 17(1), 28-40. https://doi.org/10.9744/jak.17.1.28-40

Weli. (2017). The company's internal characteristics and mandatory disclosure size of web-based financial reporting. Journal of Economics, Business, and Accountancy Ventura, 19(3), 435-446. https://doi.org/10.14414/ jebav.v19i3.627

Wiranata, Y. A., \& Nugrahanti, Y. W. (2013). Pengaruh struktur kepemilikan terhadap profitabilitas perusahaan manufaktur di Indonesia. Jurnal Akuntansi dan Keuangan, 15(1), 15-26. https://doi.org/10.9744/jak.15.1.1526 